\title{
Carbon nanomaterials in organic photovoltaic cells
}

\author{
Taehoon Kim, Seung Jae Yang and Chong Rae Park* \\ Carbon Nanomaterials Design Laboratory, Global Research Laboratory, Research Institute of Advanced Materials, and Department of \\ Materials Science and Engineering, Seoul National University, Seoul 151-744, Korea
}

\author{
Article Info \\ Received 10 August 2011 \\ Accepted 22 November 2011 \\ *Corresponding Author \\ E-mail: crpark@snu.ac.kr
}

\section{Open Access}

DOI: http://carbonlett.org/ 10.5714/CL.2011.12.4.194

This is an Open Access article distributed under the terms of the Creative Commons Attribution Non-Commercial License (http://creativecommons.org/licenses/ by-nc/3.0/) which permits unrestricted non-commercial use, distribution, and reproduction in any medium, provided the original work is properly cited.

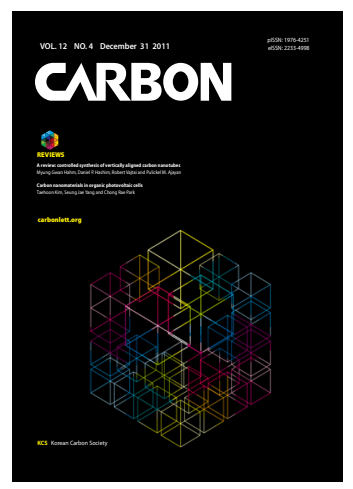

http://carbonlett.org

pISSN: 1976-4251

elSSN: 2233-4998

Copyright $\odot$ Korean Carbon Society

\begin{abstract}
Carbon nanomaterials in organic photovoltaic (OPV) cells have attracted a great deal of interest for the development of high-efficiency, flexible, and low-cost solar cells. Due to the complicated structure of OPV devices, the electrical properties and dispersion behavior of the carbon nanomaterials should be controlled carefully in order for them to be used as materials in OPV devices. In this paper, a fundamental theory of the electrical properties and dispersion behavior of carbon nanomaterials is reviewed. Based on this review, a stateof-the-art OPV device composed of carbon nanomaterials, along with issues related to such devices, are discussed.
\end{abstract}

Key words: organic photovoltaic, fullerene, carbon nanotubes, graphene, conjugated polymer

\section{Introduction}

Carbon nanomaterials have attracted a great deal of interest in electronic research areas due to their remarkable electrical properties [1,2]. Possible applications of carbon nanomaterials in electronic devices include field emission displays, transparent conducting electrodes, and solar cells. Organic photovoltaic (OPV) cells are a promising next-generation solar cell. They are lightweight and flexible devices that can be produced by low-cost and easy manufacturing methods $[3,4]$. However, the low efficiency of OPV devices is a critical issue that must be resolved before such devices can be commercialized.

Currently, most OPV cells have a bulk heterojunction (BHJ) structure composed of conjugated polymers and fullerene derivatives. The best performance obtained from a BHJ-structured OPV cell was a recorded power conversion efficiency (PCE) of $8 \%$ [5]. The synthesis of new conjugated polymers is the most feasible means of increasing the PCE at present. In contrast, the enhancement of the PCE through the tuning of fullerene derivatives has not been widely investigated. Furthermore, carbon nanotubes (CNTs) and graphene are rarely used as active materials in OPV cells in spite of their good electric properties. In that carbon nanomaterials have many interesting optoelectronic, chemical and physical properties, these nanomaterials hold considerable potential for use in OPV devices.

In this review, the fundamental theory of the solar cell is initially reviewed in an effort to understand the ideal physical properties of materials in OPV cells. We address the abovementioned issues by providing an overview of state-of-the-art carbon nanomaterials in OPV cells and go on to provide an estimate of next-generation OPV devices based on the discussion.

\section{Theoretical Consideration}

The PCE of a solar cell is given as a ratio of the output power to the irradiated light under air mass illumination of 1.5. The output power of solar cells is composed of three compo- 


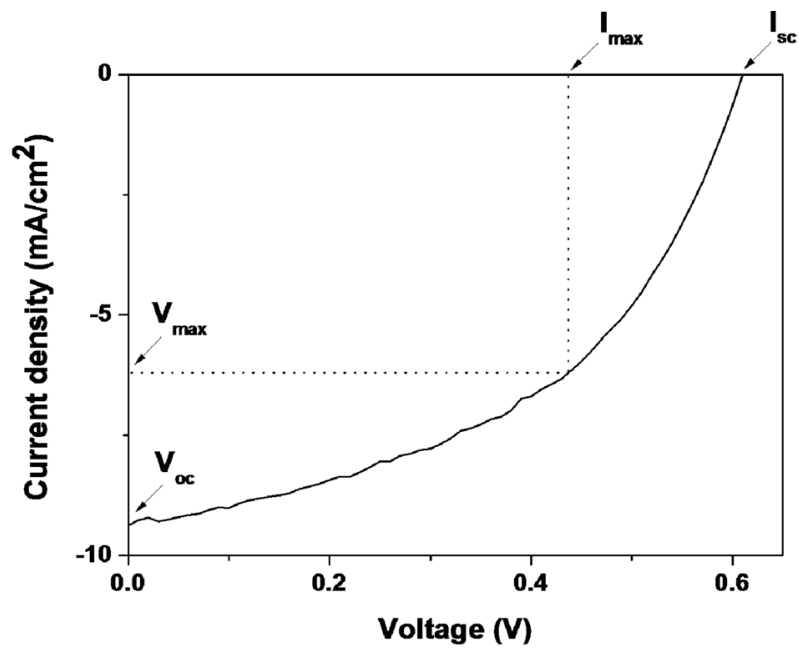

Fig. 1. Current-voltage curve of a typical organic photovoltaic cell. Output power is given by current times voltage at specific point, and $I_{\max }$ and $V_{\max }$ are the points that maximize the output power.

nents: the open circuit voltage, the short circuit current, and the fill factor. Therefore, the PCE can be expressed as Eq. (1):

$$
\mathrm{PCE}=\frac{\mathrm{P}_{\mathrm{out}}}{\mathrm{P}_{\mathrm{in}}}=\frac{\mathrm{V}_{\mathrm{max}} \times \mathrm{I}_{\mathrm{max}}}{\mathrm{P}_{\mathrm{in}}}=\frac{\mathrm{V}_{\mathrm{oc}} \times \mathrm{I}_{\mathrm{sc}} \times \mathrm{FF}}{\mathrm{P}_{\mathrm{in}}}
$$

Here, $\mathrm{P}_{\text {in }}$ denotes the solar power that reaches the solar cell and $\mathrm{P}_{\text {out }}$ is the output electrical power. Other notations are marked in Fig. 1. The physical properties, and structural and morphological changes, influence the efficiency-related components. To analyze the effects of carbon nanomaterials and to suggest a guideline for their tuning, in this paper, the effects of a structural change and of the material characteristics are reviewed first.

\subsection{Structural and morphological consideration}

Many structural concepts have been proposed during the development phase of OPV cells. The BHJ structure has shown the best performance among various structural concepts. The operation physics of OPV cells is different from that of conventional silicon solar cells due to the complicated BHJ structure. The low efficiency of CNTs and graphene-based OPV cells is induced by the unique structure of OPV devices. Therefore, a theoretical review should start with the BHJ structure of OPV devices.

A photon is able to induce the excitation of an electron in the valence band (or the highest occupied molecular orbital, the HOMO) to the conduction band (or the lowest occupied molecular orbital, the LUMO). The excited electrons and holes in the valence band are characterized by the attraction Coulombic force $\mathrm{F}$, as follows:

$$
F=-\frac{q_{1} q_{2}}{4 \pi r^{2} \varepsilon \varepsilon_{0}}
$$

In this equation, $\mathrm{q}$ is the charge, $\mathrm{r}$ is the distance between two charges, $\varepsilon$ is the dielectric constant, and $\varepsilon_{0}$ is the permittivity of free space. Therefore, the low dielectric constant of the organic material leads to a strong attraction force between the electron-hole pair.
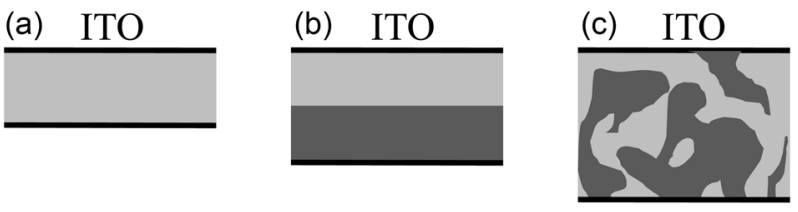

Fig. 2. Structure of an organic photovoltaic device. (a) Single-layer structure, (b) bilayer structure, (c) bulk heterojunction structure. ITO: indium tin oxide.

Because the binding energy of the electron-hole pair in an organic material $(>0.1 \mathrm{meV})$ is stronger than the thermal energy $(\sim 0.025$ $\mathrm{meV})[6]$, electrostatically bound charge carriers are formed in the organic material. These are known as excitons. The phenomenon in the organic material is opposed to the spontaneous dissociation of electron-hole pairs in silicon. The dissociation of an exciton is the main way in which the PCE is increased.

Tang addressed this problem by introducing a bilayer structure (Fig. 2b) composed of an electron donor layer and an electron acceptor layer [7]. The electron acceptor has a lower LUMO level than does the electron donor in this system. The excited electron in the electron donor is transferred to the electron acceptor due to the LUMO energy level difference between the electron donor and the acceptor. This phenomenon is known as photo-induced charge transfer, and it only takes place when the energy difference between the electron donor and the acceptor is larger than the exciton binding energy [6]. This bilayer concept greatly increases the PCE $(\sim 1 \%)[7]$.

The exciton can only be dissociated at the interface between the electron donor and the acceptor. Considering that the exciton diffusion length is small $(5 \sim 15 \mathrm{~nm})$ [8], the thickness of the electron donor should be $5 \sim 15 \mathrm{~nm}$, so as to harvest all the excitons. However, the layer has to be at least $100 \mathrm{~nm}$ wide in order to absorb light; therefore, only a small number of excitons generated near the interface can be harvested. The BHJ structure, introduced in 1995 [9], achieves both the absorption of photons and the effective dissociation of excitons. The distance from the absorption spot to the interface of the donor and acceptor pair is remarkably decreased by the interpenetration of the electron donor and the acceptor in the BHJ structure (Fig. 2c). Furthermore, this structure can be formed through a very simple process; for example, a BHJ structured OPV cell can be simply fabricated by the spin casting of a solution containing donor and acceptor materials. However, because the mixture state of the donor and acceptor determines the exciton dissociation and the charge transportation, the performance of OPV devices is too sensitive for the morphology of the active layer. Neither a large domain nor a small domain in the BHJ structure is feasible for high performance, as exciton dissociation and charge transport are ineffective for the large domain and for the small domain morphology, respectively. Therefore, an interpenetrating network with a domain size of $10 \mathrm{~nm}$ in length is the ideal morphology for both exciton dissociation and charge transport.

The dispersion of nanomaterials in a chlorinated solvent, e.g., chloroform, chlorobenzene, or dichlorobenzene, should come before the fabrication of an OPV cell, as most conjugated polymers are soluble only in a chlorinated solvent. Most OPV cells currently consist of a combination of a conjugated polymer and fullerene derivatives, especially $[6,6]$-phenyl- $\mathrm{C}_{61}$-butyric acid 
methyl ester (PCBM). In spite of the low solubility of as-synthesized fullerene, PCBM has high solubility in a chlorinated solvent due to the functional groups. PCBM-based solar cells show almost $100 \%$ exciton dissociation and greater than $90 \%$ internal quantum efficiency [10]. These findings indicate that PCBM and a conjugated polymer form a morphology that is capable of dissociating excitons and transporting charges. There have been many attempts to use titanium dioxide or zinc oxide [11-13], whose LUMO levels are similar to that of PCBM; however, the PCE levels of these types of OPV cells were low compared to those of fullerene-based solar cells. One reason for this outcome is that the morphology of these OPV cells is inappropriate for their operation as OPV cells.

Low-dimensional CNTs and graphene are favorable for the formation of a charge pathway, but the materials tend to aggregate. Nearly all studies related to dispersion have relied on trial-and-error approaches, as a rational basis for testing surface modification approaches has not been identified. The relationship between the surface characteristics of carbon nanomaterials and their dispersion in solvents should be studied on a fundamental basis. The Hansen solubility parameter may be a solution for this case, but research on the solubility parameter of carbon nanomaterials has been rare thus far.

In conclusion, from a viewpoint of the structure and morphology, the electron donor and acceptor material should form the BHJ structure without the formation of a large domain with isolated areas. PCBM is known to be an ideal material with which to formulate the BHJ structure. Its enhanced solubility, owing to the introduction of functional groups on fullerene, builds a favorable structure. Likewise, dispersion in the active layer can lead to the realization of an ideal BHJ structure with which to utilize CNT and graphene in an OPV device.

\subsection{Optoelectronic consideration}

The active materials in an OPV device should satisfy several conditions for feasible optoelectronic properties, e.g., light absorption, electrical conductivity, and semiconducting behavior. Because carbon nanomaterials have superior electrical properties, they are expected to show high performance levels in OPV devices. In addition, the electrical property of carbon nanomaterials is tunable through surface modification or by controlling the size of the material [14].

The formation of excitons in the organic material conduction band of an acceptor material should take place at a level lower than the LUMO level of the conjugated polymers in order to dissociate the exciton. Given that the LUMO levels of conjugated polymers range from $3.0 \sim 3.5 \mathrm{eV}$, the conduction band offset of the acceptor material should be lower than that of PCBM [15].

However, too low a LUMO level is also inappropriate for efficiency because such a situation leads to a low open-circuit voltage. It is generally believed that the open-circuit voltage is proportional to the difference between the LUMO level of the acceptor material and the HOMO level of the donor material (Fig. 3a). The equation of the open-circuit voltage in an OPV is generally described as follows:

$$
\mathrm{V}_{\mathrm{oc}}=\frac{\mathrm{LUMO}_{\text {Acceptor }}-\mathrm{HOMO}_{\text {Donor }}}{\mathrm{e}}-0.3 \mathrm{~V}
$$

(a)

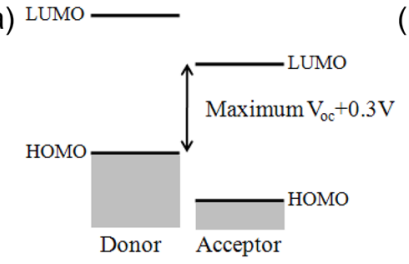

(b)

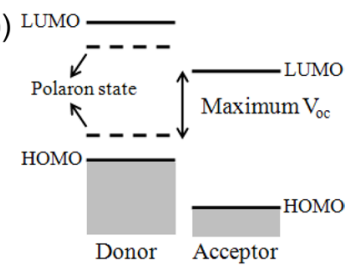

Fig. 3. (a) Maximum $V_{o c}$ as determined by the highest occupied molecular orbital (HOMO) level of the donor and the lowest occupied molecular orbital (LUMO) level of the acceptor, (b) maximum $\mathrm{V}_{\text {oc }}$ as determined by the SOMO level of the donor and the LUMO level of the acceptor.

The physical meaning of the last term, $0.3 \mathrm{~V}$, in Eq. (3) is somewhat obscure. Cravino [16] suggested that the open-circuit voltage is determined by the polaron state of the donor and the LUMO level of the acceptor (Fig. 3b). The difference between the polaron state and the HOMO level is normally $0.2 \sim 0.4 \mathrm{~V}$, which is correlated with the $0.3 \mathrm{~V}$ value in Eq. (3). In terms of the open-circuit voltage, a high LUMO level is favorable to increase the PCE as long as the acceptor material dissociates the excitons.

Because a metallic material acts as a recombination center [17], the incorporation of a metallic material in the active layer of an OPV device is inappropriate. In contrast to the semiconducting behavior of fullerene, the electrical properties of CNTs and graphenes are metallic. This primarily explains the slow development of CNTs and graphenes in OPV devices. The metallic material film can be used as a charge-transport layer, e.g., poly(3,4-ethylenedioxythiophene):poly(styrenesulfona te) (PEDOT:PSS), of the type generally used in OPV devices these days. However, energy level alignment and transparency become issues when using these materials as charge-transport layers.

The charge mobility of the active material influences the transportation after exciton dissociation. Because the electron and the hole tend to be recombined by electric force-even after exciton dissociation-the charges should move to the electrode rapidly. Therefore, the material used in the active layer should have high charge mobility so as to transport the dissociated charges. Another important condition for a high short-circuit current is the balance between the hole and electron mobility of the donor/acceptor pair. When the mobility of one charge is much higher than that of the other, the charge accumulates in the active layer. This accumulation of charge generates an unfavorable electric field and hampers the transportation of the charge carrier [18]. In that the charge mobility of the conjugated polymer is in the range of $10^{-3} \sim 10^{-4} \mathrm{~cm}^{2} / \mathrm{Vs}$ [19-22], the charge mobility of the acceptor material should be in this region as well.

Therefore, semiconducting materials that have a conduction band offset of approximately $4.0 \mathrm{eV}$ are proper acceptor materials. Because carbon nanomaterials show various electrical properties based on their microstructural changes and surface characteristics, target-oriented carbon nanomaterials can be prepared by tuning.

\section{Fullerene}

Fullerene derivatives are at present known to be the best electron acceptor material in an OPV device. $\mathrm{C}_{60}$ derivatives have 


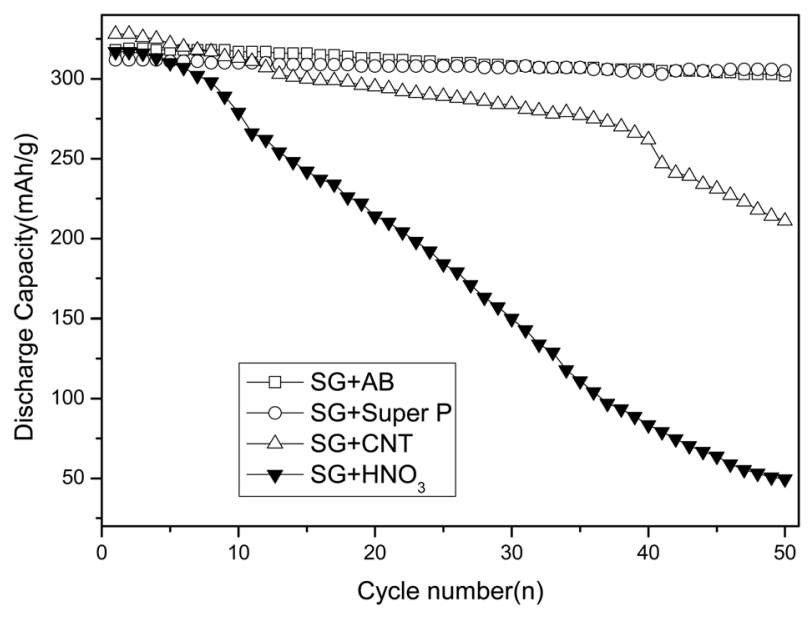

Fig. 4. UV/vis spectra of PCBM (dotted line) [32], PCBM (dashed line) [33], and PCBM (straight line) [34], all in toluene. Reprinted with permission from [25]. Copyright 2006 American Chemical Society.

been the most widely studied fullerenes, but $\mathrm{C}_{70}$ and $\mathrm{C}_{84}$ derivatives have also been investigated as electron acceptor materials. PCBM is the best-known fullerene derivative in research related to the development of OPV devices. Nowadays, new derivatives are being introduced to increase the PCE. Based on the theoretical consideration in the last chapter, the state of the art and the material features of fullerene are reviewed in this chapter.

\subsection{Optoelectronic properties of fullerene}

Considering that fullerene is a semiconducting material with a low LUMO level, it effectively dissociates excitons in conjugated polymers. The photoluminescence of a conjugated polymer is completely quenched by introducing fullerene derivatives [23], which indicates the complete dissociation of excitons. The LUMO level of the electron acceptor also influences the opencircuit voltage of an OPV device; therefore, the tuning of the LUMO level influences the level of efficiency. The LUMO level of fullerene can be changed by either the introduction of functional groups on the surface of the fullerene [24] or through the use of a different type of fullerene [25].

It has been reported that the electron mobility of a single crystal of fullerene was on the order of $10^{-1} \sim 10^{0} \mathrm{~cm}^{2} / \mathrm{Vs}[26,27]$. Surface modification reduces the electron mobility due to the crystallinity of the material. The electron mobility of $\mathrm{PC}_{60} \mathrm{BM}$ is less than the mobility $\left(10^{-3} \sim 10^{-1} \mathrm{~cm}^{2} / \mathrm{Vs}\right)$ of $\mathrm{C}_{60}$ [28-30], which is similar to the hole mobility of poly(3-hexylthiophene) (P3HT, $\left.10^{-3} \sim 10^{-1} \mathrm{~cm}^{2} / \mathrm{Vs}\right)[20,21]$. Therefore, $\mathrm{PC}_{60} \mathrm{BM}$ has many advantages when used in the active layer of an OPV device with P3HT.

The narrow absorption spectrum of fullerene, especially in the visible range, prevents the harvesting of photons. Fig. 4 illustrates the absorption spectrum of fullerene derivatives. As a low absorption coefficient is induced by the high structural symmetry of $\mathrm{C}_{60}$ [31], enhancement of the absorption in fullerene by destruction of the symmetry will increase the overall short-circuit current. $\mathrm{C}_{70}$ has a high absorption coefficient in the visible region because it has lower symmetry compared to $\mathrm{C}_{60}$ [31].

\subsection{Fullerene derivatives in OPV devices}

Due to the advantages mentioned in the previous section, fullerene derivatives have been widely adopted as electron acceptor materials in solution processed OPV devices. Indeed, OPV devices capable of more than 5\% efficiency adopt fullerene derivatives as an electron acceptor. Specifically, the incorporation of $\mathrm{PC}_{70} \mathrm{BM}$ and a low-bandgap polymer shows high performance levels due to the high absorption coefficient in the visible light range of $\mathrm{PC}_{70} \mathrm{BM}$ (Fig. 4) [31].

Due to the unique structure of OPV devices, the formation of an optimized BHJ structure to enhance exciton harvesting and charge transportation has been an important issue. Many studies of the effect of solvents [35,36], functional groups of fullerene [24,37], thermal annealing [38-40], and the ratio of a conjugated polymer to fullerene $[41,42]$ have been performed in an effort to find the optimized condition. Furthermore, the mixture state of the material decreases the electronic mobility of the material; for example, both the electron mobility of PCBM and the hole mobility of P3HT in the BHJ structure have been determined to be $10^{-4} \sim 10^{-5} \mathrm{~cm}^{2} / \mathrm{Vs}[43,44]$, which is lower than the value of a single material. The experimental conditions related to the morphology affect the crystallinity and mobility of the materials in a mixture.

The type of solvent used simultaneously influences the electronic property and morphology of the active layer. A solvent with a high boiling point allows the conjugated polymer and the fullerene enough time to become crystallized. While chloroform is too volatile to be crystallized completely, chlorobenzene and o-dichlorobenzene are known to be good solvents due to their high boiling points [45]. The mobility can be varied by controlling the film growth rate with the same solvent. Slow-grown film has higher mobility, low resistance, and a high fill factor [43].

Solubility is a critical factor that influences the PCE because the morphology of the active layer changes significantly. Because the solubility of PCBM in chlorobenzene is more than twice its solubility in toluene, a chlorobenzene-cast OPV device has higher efficiency [36]. The poor solvent usually forms an "island" in the active layer, thus preventing effective exciton dissociation and charge transport. Xylene is another example of a poor solvent for PCBM; an active layer consisting of xylene forms many islands [35].

Thermal annealing is another method of controlling both the electric mobility and the morphology of the active layer. High crystallinity and a large domain induced by annealing enhance the electron mobility by a factor of 30 [44]. Fig. 5 shows the morphological differences after the annealing of P3HT and P3HT/PCBM films. To achieve an optimized domain growth for exciton dissociation and charge transportation, several attempts were made to determine the appropriate annealing temperature. Through this process, it was found that annealing at $150^{\circ} \mathrm{C}$ is the best condition for the P3HT and PCBM combination [38].

Surface-modified fullerene that has a fluorocarbon chain behaves as a hole blocking layer and forms a dipole layer between the active layer and the electrode [46]. The fullerene derivative layer increases the fill factor by reduction of serial resistance since the dipole moment of the layer changes the energy level. LiF typically forms a dipole layer in organic electronics, but fullerene derivatives play a similar role by means of solution processing. 

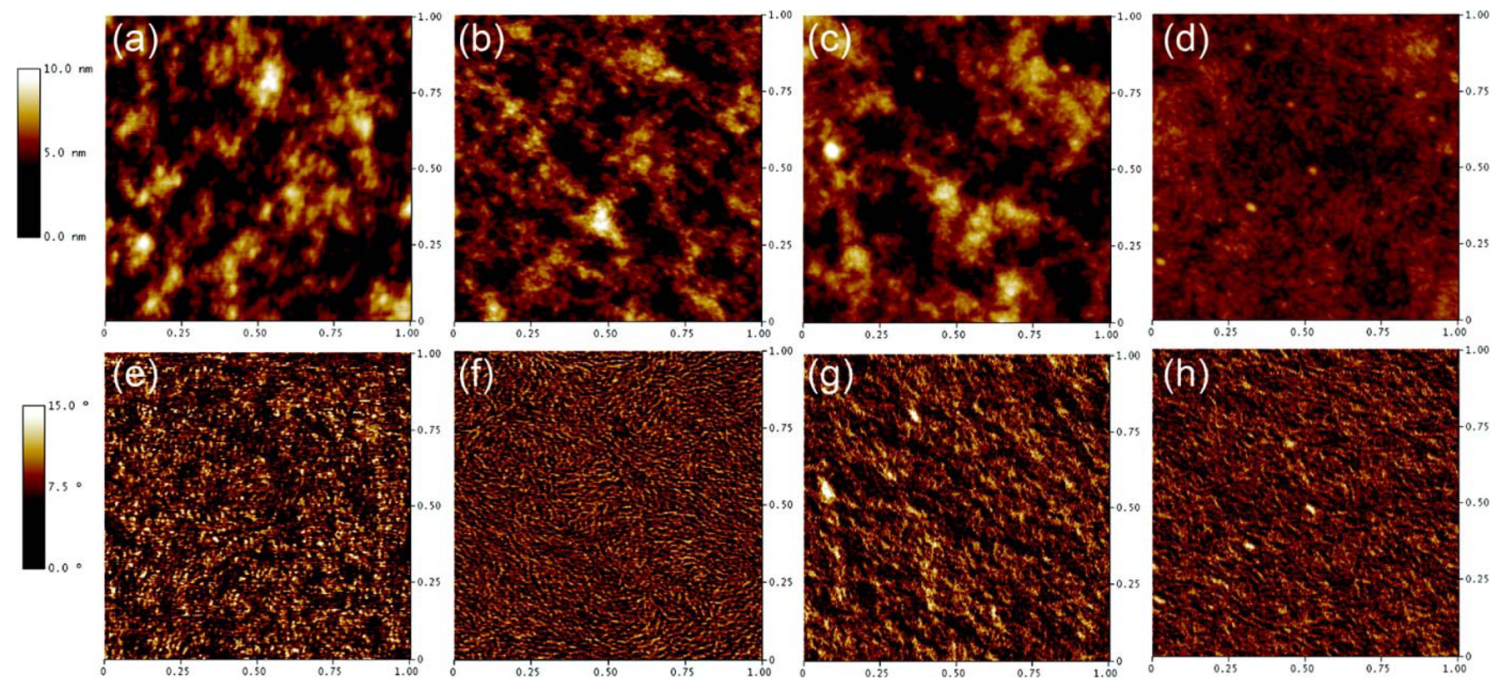

Fig. 5. Tapping mode AFM topographic (top) and phase (bottom) images $(1 \mu \mathrm{m} \times 1 \mu \mathrm{m})$ of as-cast and annealed films of pure $\mathrm{P} 3 \mathrm{HT}$ (a, $\mathrm{b}, \mathrm{e}, \mathrm{f})$ and the P3HT:PCBM blend (c, d, g, h). Reprinted with permission from [39]. Copyright 2008 American Chemical Society.

The grafting of fullerene and a conjugated polymer is one way to optimize the morphology of the active layer. The grafted structure becomes what is known as a "double cable polymer," which is composed of a conjugated polymer and fullerenes attached to a polymer backbone as a branch. This prevents the formation of too large a domain and maximizes the contact between the donor and the acceptor $[47,48]$

Recently, the increase in the open-circuit voltage has become an issue in efforts to enhance the PCE. Many research groups have concentrated on the synthesis of new conjugated polymers with a low LUMO level in order to achieve a high open-circuit voltage. In contrast, other attempts have been made to increase the open-circuit voltage by tuning the LUMO level of the electron acceptor. Indeed, $6.5 \%$ efficiency without the synthesis of a new conjugated polymer was achieved with the indene- $\mathrm{C}_{60}$ bisadduct [49]. The incorporation of P3HT and indene- $\mathrm{C}_{60}$ bisadduct increased the opencircuit voltage by nearly $40 \%$ compared to the conventional incorporation of P3HT and PCBM. Because the synthesis of a new conjugated polymer is complicated and time-consuming work, the tuning of fullerene derivatives to enhance the opencircuit voltage will be a critical issue for next-generation OPV devices.

\section{CNTs}

During the last twenty years, numerous studies of CNTs have been performed due to their fascinating physical properties. CNTs offer a solution-processible route to inexpensive and large area fabrication; hence, the incorporation of CNTs and a conjugated polymer has potential for OPV devices. Nevertheless, the combination of CNTs and a conjugated polymer has hardly been investigated thus far due to the electronic properties and the dispersibility of the CNTs. Therefore, these two topics are discussed in this section in terms of photovoltaic applications.

\subsection{Surface modification and dispersion of CNTs}

Surface modification of CNTs can be achieved by mechanical [50,51], physicochemical [52-56], or irradiation methods $[57,58]$. In this review, we focus on the facile physicochemical approach, which is the most widely studied method. The surface modification of CNTs was reviewed in an earlier paper [59].

Physicochemical surface modification can be divided into two methods: covalent surface modification and non-covalent surface modification. Covalent surface modifications have been widely studied, and many modification techniques have been suggested, including oxidation [55,56], fluorination [52], thiolation [53] and amidation [54]. These methods can be categorized into first-generation (denoted as $1 \mathrm{G}$ ) and second-generation (denoted as $2 \mathrm{G}$ ) modification approaches on the basis of whether or not the surface-modified group is directly attached to the sidewalls or the ends of the CNTs [59]. Various surface modifiers have been introduced by covalent surface modification methods, but a reduction in the electronic performance of CNTs is inevitably due to the partial disruption of the sidewall $\mathrm{sp}^{2}$ hybridization system.

Generally, organic mediating molecules ranging from lowmolecular-weight molecules to polymers are used in non-covalent surface modification applications. Because this method preserves $\mathrm{sp}^{2}$-conjugated structures and the electronic performance of the CNTs, it has an advantage over covalent surface modification in an OPV device. The mediating molecules change the surface characteristics of the CNTs by either adsorbing onto them or wrapping around them. Surfactants such as sodium dodecylsulfate $[60,61]$ and Triton $X[61]$ enhance the dispersion of CNTs by adsorbing onto their surfaces. The dispersibility of the adsorbed CNTs varies depending on the type of surfactant. Some polymers improve the dispersibility by wrapping around the CNTs. P3HT is a surface-mediating polymer due to its strong $\pi-\pi$ interactions with CNTs [62]. The dispersibility can be enhanced further by the introduction of a block copolymer, e.g., the P3HT-b-PS block copolymer [34]. 
Table 1. Surface modifications of CNTs for dispersion in chlorinated solvents

\begin{tabular}{|c|c|c|c|c|c|c|}
\hline CNT & Solvent & $\begin{array}{c}\text { Classification of } \\
\text { surface modification }\end{array}$ & $\begin{array}{l}\text { Modification } \\
\text { methodology }\end{array}$ & Introduced surface group & $\begin{array}{l}\text { Dispersibility } \\
(\mathrm{mg} / \mathrm{mL})\end{array}$ & Ref. \\
\hline MWCNT & $\mathrm{CHCl}_{3}$ & $1 \mathrm{G}$ & Cycloaddition & $-\mathrm{NR}$ & 50 & [63] \\
\hline SWCNT & $\mathrm{CHCl}_{3}$ & $2 \mathrm{G}$ & Grafting to & ODA & 0.05 & [64] \\
\hline MWCNT & $\mathrm{CHCl}_{3}$ & $2 \mathrm{G}$ & Grafting to & Triethylenetetramine & & {$[65]$} \\
\hline MWCNT & $\mathrm{CHCl}_{3}$ & Noncovalent & Wrapping & Polystyrene & 0.066 & [66] \\
\hline SWCNT & $\mathrm{CHCl}_{3}$ & Noncovalent & Wrapping & Pyrene-capped polystyrene & 0.25 & [67] \\
\hline SWCNT & $\mathrm{CHCl}_{3}$ & Noncovalent & Wrapping & P3HT-b-PS & 2.5 & [68] \\
\hline SWCNT & $\mathrm{CHCl}_{3}$ & Noncovalent & Wrapping & Oligo(m-phenylene ethylene)s & 0.1 & [69] \\
\hline SWCNT & $\mathrm{CHCl}_{3}$ & Noncovalent & Wrapping & Polypeptide & 0.068 & [70] \\
\hline MWCNT & Toluene & Noncovalent & Adsorption & Gemini surfactant & 0.1 & [71] \\
\hline
\end{tabular}

MWCNT: multi-walled carbon nanotube, SWCNT: single-walled carbon nanotube, 1G: first-generation, 2G: second-generation.

Ultimately, the purpose of surface modification is to tailor-fit the required dispersion of the CNTs to a specific solvent and polymer. CNT surfaces should be designed for the dispersion of a chlorinated solvent and for miscibility with a conjugated polymer for use in an OPV device. Table 1 summarizes several representative surface modification techniques of CNTs for dispersion in chlorinated solvents.

Because electronic device applications require the preservation of the electrical and electronic properties of CNTs, noncovalent surface modification methods are preferred. However, because most organic mediating molecules are insulating materials, surface modifiers should either be removed [33] or else be conductive $[59,72]$ if used with electronic device.

\subsection{Electronic properties of CNTs}

The formation of single-walled CNTs (SWCNTs) can be envisioned as the rolling of a piece of graphene. The electronic properties of SWCNTs are discussed on the basis of those of graphene, but the band structure changes upon rolling along a chiral vector, as defined by the two integers $n$ and $\mathrm{m}$ [1]. The electronic properties of SWCNTs become metallic when $n-m=3 N$ [1]. When $n-m \neq 3 N$, on the other hand, the SWCNTs have a nonzero bandgap. Metallic SWCNTs and semiconducting SWCNTs coexist in as-synthesized SWCNTs. In contrast, MWCNTs have a metallic property. Metallic CNTs decrease the performance of an OPV cell because they act as recombination and trap centers [17]; hence, separation of the metallic SWCNTs and semiconducting SWCNTs is necessary beforehand. Ultracentrifugation with DNA wrapping [73] and a thermal treatment [74] have been suggested for this separation.

The work functions of SWCNTs and MWCNTs are known to be 4.5 5.9 eV [75] and 4.3 4.95 eV [76], respectively. The work function can be tuned by means of oxidation [76] or by doping with either nitrogen or boron [77]. This tunable work function contributes to the charge selectivity of CNTs.

The electrical mobility of CNTs in a field-effect transistor is reported to be $79000 \mathrm{~cm}^{2} / \mathrm{Vs}$ at room temperature. The esti- mated intrinsic mobility is even higher [2]. The mobility is too high for CNTs to be used as an electron acceptor incorporated with a conjugated polymer due to the charge balance. Instead, the application of CNTs in the charge-transport layer is being studied due to the high electrical mobility of CNTs.

\subsection{CNTs in OPV devices}

Studies of CNTs in OPV devices can be categorized into three groups. First, some researchers have used CNTs as an electron acceptor material to replace fullerene derivatives. The PCE of an OPV cell composed of poly(3-octylthiophene) and SWCNTs has been shown to be $0.04 \%$ [78]. Interestingly, in spite of the low PCE, the open-circuit voltage of the OPV cell is high $(0.75 \mathrm{~V})$ compared to conventional fullerenebased OPV cells. High open-circuit voltage was also noted in another paper [79], but the overall efficiency was still low. There have been many attempts to increase the PCE. To improve the miscibility between conjugated the polymer and the CNTs, surface modification techniques were utilized as a means to attach a thiophene group on the surface [80]. Dye molecules were adsorbed onto the CNTs to enhance the photogeneration of the CNTs [81] (Fig. 6). Nevertheless, the PCE of the OPV cells with CNT acceptors is low compared to that of fullerene-based OPV cells.

A second application is as a charge-transport layer in an OPV device. Because CNTs have a remarkably high level of electronic mobility and a work function similar to that of the electrode, CNTs are good candidates for use in the charge-transport layer. Indeed, many studies have reported the enhancement of PCE by insertion of CNTs as transporting layer. Due to the high work function of CNTs, CNTs are mainly effective in hole transportation [82-84]. The high mobility of CNTs improves the PCE by increasing the carrier transport capabilities. Because the work function can be altered by a post-treatment procedure, it is expected that the charge carrier transport also can be tuned. Indeed, the work function of MWCNTs can be changed to 4.4 $\mathrm{eV}$ and $5.2 \mathrm{eV}$ by $\mathrm{n}$-doping and $\mathrm{p}$-doping, respectively. According to a charge transportation results in an electron-only device 

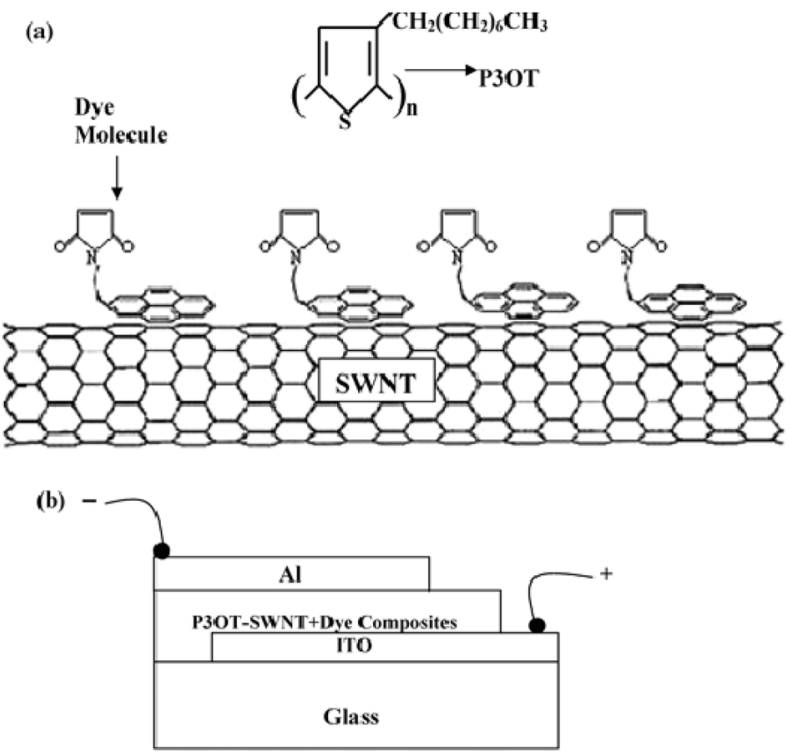

Fig. 6. (a) Detailed scheme of the dye molecule (PM) attachment to the single-walled carbon nanotube (SWNT) surface, and (b) device architecture of the photovoltaic cell. Reprinted with permission from [81]. Copyright 2004 American Chemical Society.

and a hole-only device, the n-doping and p-doping of MWCNTs were found to have enhanced only the electron transport and the hole transport, respectively [77]. This indicates that the end-use tailor-fit tuning of CNTs is possible in electronic applications.

Electron acceptors such as PCBM or inorganic nanomaterials can be combined with CNTs by a post-treatment procedure involving the two materials [32] or by growing these materials on the surface of CNTs [85]. In these cases, the electron transferred from the conjugated polymer to the acceptor can be transported to the electrode through the CNTs.

Lastly, CNTs have been used as an electrode for an OPV cell $[33,86]$. Large-area and low-cost transparent conducting film composed of CNTs is a promising application owing to the high conductivity and low percolation threshold concentration of the CNTs. This type of CNT electrode has also been investigated in OPV devices. There is research available on this topic [87].

Tables 2 and 3 summarize the reported OPV devices that adopt CNTs as an electron acceptor and charge-transport layer. The trends in the research highlight the possible application of CNTs in OPV devices as a charge-transport layer.

\section{Graphene}

Graphene has attracted attention due to its remarkable electronic, mechanic, and thermal properties since the mechanical exfoliation technique was introduced in 2004 [92]. A scalable process is also possible now with the chemical oxidation of graphite and the reduction of graphite oxide [93]. Because graphene is also amenable to solution processing, studies of the incorporation of graphene into OPV devices are ongoing. The physical properties of graphene are tuned according to the number of layers [94,95], the lateral size and the $\mathrm{C} / \mathrm{O}$ ratio $[14,94,96]$, and by surface modification techniques [97]. Therefore, chemical oxidation and reduction processes influence the physical properties of graphene. Taken together, these findings indicate that the preparation of graphene must be done carefully.

Table 2. OPV devices composed of a conjugated polymer and CNTs as an electron acceptor

\begin{tabular}{|c|c|c|c|c|c|c|}
\hline Donor & Acceptor & $V_{\text {oc }}(V)$ & $\mathrm{I}_{\mathrm{sc}}\left(\mathrm{mA} / \mathrm{cm}^{2}\right)$ & FF & PCE (\%) & Ref. \\
\hline P3OT & SWCNT & 0.75 & 0.12 & 0.4 & 0.04 & [77] \\
\hline P3OT & SWCNT & 0.98 & 0.12 & - & - & [78] \\
\hline P3OT & SWCNT-THIOP & 0.75 & 0.0095 & - & 0.184 & [79] \\
\hline MO-PPV & SWCNT & 0.49 & 0.0229 & 0.26 & 0.0042 & [88] \\
\hline
\end{tabular}

Table 3. OPV devices composed of a conjugated polymer and CNTs as a charge-transport layer

\begin{tabular}{lccccccc} 
Donor & Acceptor & Transport layer & $\mathbf{V}_{\text {oc }}(\mathbf{V})$ & $\mathbf{I}_{\text {sc }}\left(\mathbf{m A} / \mathbf{c m}_{\mathbf{2}}\right)$ & FF & PCE $(\mathbf{\%})$ & Ref. \\
\hline P3HT & PCBM & Boron doped MWCNT & 0.57 & 11.47 & 0.613 & 4.1 & {$[77]$} \\
\hline P3OT & N-(1-pyrenyl)maleimide & SWCNT & 0.6 & 0.18 & 0.35 & 0.036 & {$[81]$} \\
\hline P3HT & PCBM & MWCNT & 0.567 & 9.33 & 0.384 & 2.0 & {$[82]$} \\
\hline P3HT & PCBM & SWCNT, MWCNT & 0.61 & 7.3 & 0.62 & 2.7 & {$[83]$} \\
\hline P3HT & C60 & SWCNT & 0.386 & 2.72 & 0.512 & 0.57 & {$[32]$} \\
\hline P3OT & CdSe & SWCNT & 0.75 & 0.00016 & - & - & {$[89]$} \\
\hline P3HT & PCBM & SWCNT & 0.55 & 4.95 & 0.52 & 1.4 & {$[90]$} \\
\hline P3HT & PCBM & SWCNT-CONHTh & 0.55 & 5.6 & 0.58 & 1.78 & {$[91]$} \\
\hline
\end{tabular}


Table 4. OPV devices composed of a conjugated polymer and graphene as an electron acceptor

\begin{tabular}{cccccccc} 
Donor & Acceptor & Solvent & $\mathrm{V}_{\mathrm{oc}}(\mathrm{V})$ & $\mathrm{I}_{\mathrm{sc}}\left(\mathrm{mA} / \mathrm{cm}^{2}\right)$ & FF & PCE $(\%)$ & Ref. \\
\hline P3HT & Phenyl isocyanate treated graphene & 1,2-Dichlorobenzene & 0.72 & 4.0 & 0.38 & 1.1 & {$[108]$} \\
\hline P3HT & Graphene oxide & Chloroform & - & - & - & - & {$[109]$} \\
\hline P3OT & Phenyl isocyanate treated graphene & 1,2-Dichlorobenzene & 0.92 & 4.2 & 0.37 & 1.4 & {$[110]$} \\
\hline
\end{tabular}

\subsection{Optoelectronic properties of graphene}

Graphene shows very interesting and unique electronic properties. For example, it is described as a zero-gap semiconductor. In addition, electrons in graphene behave as a zero-rest mass [98]. In terms of OPV devices, graphene has extremely high electronic mobility (200 $\left.000 \mathrm{~cm}^{2} / \mathrm{Vs}\right)$ [99] and a work function of $4.5 \mathrm{eV}$ [100]. Due to the similarity of the electronic properties of graphene and those of CNTs, it is expected that graphene might also be a favorable material for use in the charge-transport layer.

When the width of graphene is reduced and the graphene becomes a one-dimensional nanoribbon, the bandgap is open [96]. The bandgap of the graphene nanoribbon that can be obtained by the chemical method [101] scales inversely with the width of the graphene. The mobility of the graphene nanoribbon decreases to $100 \mathrm{~cm}^{2} / \mathrm{Vs}$, but the mobility is still much higher than that of conjugated polymers. Another structural parameter, that is, the number of layers, also influences the electrical property of graphene. For example, the bandgap of bilayer graphene opens when a strong perpendicular electric field is applied [95]. The mobility of graphene also decreases in bilayer or multilayer graphene [94].

Oxidative groups on graphene degrade its electrical property; however, chemical exfoliation methods inevitably produce an oxidative group during the oxidation process. Therefore, reduction of the oxidative groups on the surface of the graphene edge is one of the main issues in research efforts that seek to obtain ideally operating graphene. Hydrazine [102], $\mathrm{NaBH}_{4}$ [103], and hydroiodic acid [104] are the most widely used reduction agents, along with the method of thermal annealing in hydrogen atmosphere [105]. The atomic ratio $\mathrm{C} / \mathrm{O}$ of reduced graphene indicates the reduction efficiency; it is closely correlated with the conductance of reduced graphene [106]. The work function of graphene oxide $(\sim 4.9 \mathrm{eV})$ [107] is higher than that of singlelayer graphene $(\sim 4.57 \mathrm{eV})$ and of bilayer graphene $(\sim 4.69 \mathrm{eV})$ [100]. This is also true for CNTs and oxidized CNTs.

\subsection{Graphenes in OPV devices}

Studies of graphene as an electron acceptor in an OPV device have been underway since 2008 [108]. The solubility of graphene is crucial in the formation of the BHJ structure in the active layer. Therefore, graphene oxide [109] or functionalized graphene oxide $[108,110]$ can be used for the fabrication of an OPV device. Because this research area is in its early stages, there are only a few studies of graphene acceptors. Table 4 summarizes the results pertaining to OPV devices composed of a conjugated polymer and graphene. Interestingly, the power conversion efficiencies are much higher than the efficiency of OPV
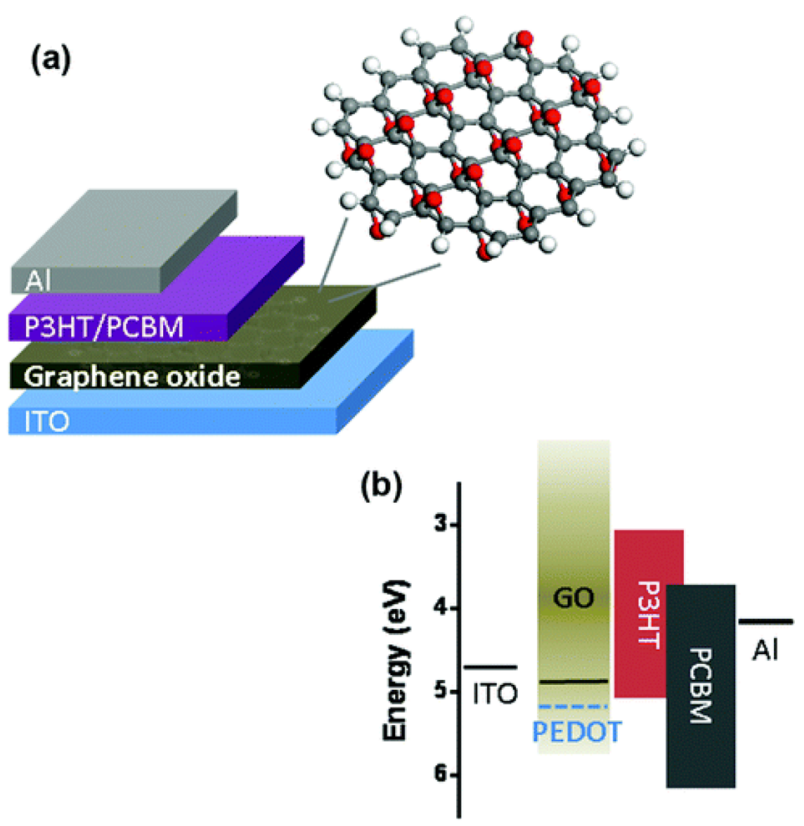

Fig. 7. (a) Schematic of the photovoltaic device structure consisting of the following: ITO/GO/P3HT:PCBM/Al. (b) Energy level diagrams of ITO, interlayer materials (PEDOT:PSS, GO), P3HT (donor), and PCBM (acceptor), and Al. Reprinted with permission from [107]. Copyright 2010 American Chemical Society. ITO: indium tin oxide, P3HT: poly(3-hexylthiophene), PCBM: [6,6]-phenyl- $C_{61}$-butyric acid methyl ester.

devices composed of a conjugated polymer and CNTs.

CNTs show poor performance as electron acceptors in OPV devices due to their metallic properties. Likewise, graphene in the charge-transport layer [107,111-113] or in transparent conducting film also shows better performance than does a graphene acceptor. The research trends regarding graphene in OPV devices are quite similar to those related to CNTs in OPV devices. For example, graphene is used as a hole transport layer $[107,112,113]$ due to its high work function (Fig. 7), or fullerene-grafted graphene is adopted as an electron acceptor and an electron transport layer [111]. In spite of the enhancement in the performance of OPV devices with incorporated graphene, a breakthrough is necessary before such devices can compete with a fullerene-based OPV devices.

\section{Outlook and Conclusions}

Fullerene derivatives are the most suitable materials for use as electron acceptors in OPV devices due to their electrical and morphological characteristics, such as their energy level, electron mobility, solubility, and miscibility with conjugated poly- 
Table 5. OPV devices composed of a conjugated polymer and graphene as a charge-transport layer

\begin{tabular}{ccccccccc} 
Donor & Acceptor & Transport layer & $\mathbf{V}_{\text {oc }}(\mathbf{V})$ & $\mathbf{I}_{\text {sc }}\left(\mathbf{m A} / \mathbf{c m}^{2}\right)$ & FF & PCE $(\mathbf{\%})$ & Ref. \\
\hline P3HT & PCBM & Graphene oxide & 0.57 & 11.40 & 0.543 & 3.5 & {$[107]$} \\
\hline P3HT & C60 & Reduced graphene & 0.56 & 4.45 & 0.49 & 1.22 & {$[111]$} \\
\hline P3HT & PCBM & NiO $_{x} /$ Graphene oxide & 0.602 & 8.71 & 0.664 & 3.48 & {$[112]$} \\
\hline P3HT & PCBM & Graphene oxide/PEDOT:PSS & 0.62 & 14.2 & 0.43 & 3.8 & {$[113]$} \\
\hline P3HT & PCBM & Graphene oxide & 0.57 & 10.30 & 0.53 & 3.10 & {$[114]$} \\
\hline
\end{tabular}

mers. The development of indene- $\mathrm{C}_{60}$ bisadduct has shown that an enhancement of the PCE is possible with conventional conjugated polymers. The design of fullerene derivatives tailor-made for new conjugated polymers is required because the electrical and morphological characteristics of new conjugated polymers are different from each other.

CNTs and graphene are regarded as the best materials for use as transparent conducting electrodes due to their high electric conductivity. Although ITO is currently the main transparent conducting electrode, the carbon electrode system will advance due to the depletion of indium and the requirements for flexible devices. One potential application of CNTs and grapheme is as a carrier transport layer in an OPV device, which is possible as long as the carbon nanomaterials are miscible with a conjugated polymer. As a result, all components except conjugated polymers in an OPV device can be replaced by carbon materials.

Pristine CNTs and graphene are not suitable for use as active materials in OPV devices due to the metallic properties of the materials. The selective growth of semiconducting SWCNTs, semiconducting cup-stacked CNTs [115], or graphene nanoribbon may be a candidate as a next-generation acceptor, but many aspects should be considered further-both theoretically and experimentally.

Due to the stability problem associated with conjugated polymers, OPV devices have an inevitable lifetime limitation. Encapsulation or the use of an inverted structure may help avoid the stability issue, but both will restrict the fabrication condition. If carbon materials replace conjugated polymers, solutionprocessible, air-stable, and wafer-free solar cells can be created. The formation of a $p-n$ junction of carbon nanomaterials for the operation of diodes has been suggested in several studies [116]. However, the performance of these materials should be improved further if they are to compete with other solar cells.

Currently, carbon nanomaterials are indispensable for the operation of OPV cells. To realize high-performance, flexible, and chemically stable OPV devices, the role of carbon nanomaterials in OPV devices must be explored further. It is expected that deeper theoretical consideration and a greater understanding of carbon nanomaterials will lead to the availability of high-performance solar cells.

\section{Acknowledgements}

This work was supported by the National Research Foundation of Korea (NRF) grant funded by the Korea government (MEST) [No. 2010-0029244].

\section{References}

[1] Avouris P, Chen Z, Perebeinos V. Carbon-based electronics. Nature Nanotechnol, 2, 605 (2007). http://dx.doi.org/10.1038/nnano.2007.300.

[2] Durkop T, Getty SA, Cobas E, Fuhrer MS. Extraordinary mobility in semiconducting carbon nanotubes. Nano Lett, 4, 35 (2004). http://dx.doi.org/10.1021/n1034841q.

[3] Gunes S, Neugebauer H, Sariciftci NS. Conjugated polymer-based organic solar cells. Chem Rev, 107, 1324 (2007). http://dx.doi. org/10.1021/cr050149z.

[4] Dennler G, Scharber MC, Brabec CJ. Polymer-fullerene bulk-heterojunction solar cells. Adv Mater, 21, 1323 (2009). http://dx.doi. org/10.1002/adma.200801283.

[5] Chen HY, Hou J, Zhang S, Liang Y, Yang G, Yang Y, Yu L, Wu Y, Li G. Polymer solar cells with enhanced open-circuit voltage and efficiency. Nature Photon, 3, 649 (2009). http://dx.doi.org/10.1038/ nphoton.2009.192.

[6] Gregg BA. Excitonic solar cells. J Phys Chem B, 107, 4688 (2003). http://dx.doi.org/10.1021/jp022507x.

[7] Tang CW. Two-layer organic photovoltaic cell. Appl Phys Lett, 48, 183 (1986). http://dx.doi.org/10.1063/1.96937.

[8] Mayer AC, Scully SR, Hardin BE, Rowell MW, McGehee MD. Polymer-based solar cells. Mater Today, 10, 28 (2007). http:// dx.doi.org/10.1016/s1369-7021(07)70276-6.

[9] Yu G, Gao J, Hummelen JC, Wudl F, Heeger AJ. Polymer photovoltaic cells: enhanced efficiencies via a network of internal donoracceptor heterojunctions. Science, 270, 1789 (1995). http://dx.doi. org/10.1126/science.270.5243.1789.

[10] Park SH, Roy A, Beaupre S, Cho S, Coates N, Moon JS, Moses D, Leclerc M, Lee K, Heeger AJ. Bulk heterojunction solar cells with internal quantum efficiency approaching 100\%. Nature Photon, 3, 297 (2009). http://dx.doi.org/10.1038/nphoton.2009.69.

[11] Coakley KM, Liu Y, McGehee MD, Frindell KL, Stucky GD. Infiltrating semiconducting polymers into self-assembled mesoporous titania films for photovoltaic applications. Adv Funct Mater, 13, 301 (2003). http://dx.doi.org/10.1002/adfm.200304361.

[12] Beek WJE, Wienk MM, Janssen RAJ. Hybrid solar cells from regioregular polythiophene and $\mathrm{ZnO}$ nanoparticles. Adv Funct Mater, 16, 1112 (2006). http://dx.doi.org/10.1002/adfm.200500573.

[13] Chang CH, Huang TK, Lin YT, Lin YY, Chen CW, Chu TH, $\mathrm{Su}$ WF. Improved charge separation and transport efficiency in poly(3- hexylthiophene)-TiO2 nanorod bulk heterojunction solar cells. J Mater Chem, 18, 2201 (2008). http://dx.doi.org/10.1039/ b800071a.

[14] Jeong HK, Jin MH, So KP, Lim SC, Lee YH. Tailoring the char- 
acteristics of graphite oxides by different oxidation times. J Phys D: Appl Phys, 42, 065418 (2009). http://dx.doi.org/10.1088/00223727/42/6/065418.

[15] He Y, Chen HY, Hou J, Li Y. Indene - C60 bisadduct: a new acceptor for high-performance polymer solar cells. J Am Chem Soc, 132, 1377 (2010). http://dx.doi.org/10.1021/ja908602j.

[16] Cravino A. Origin of the open circuit voltage of donor-acceptor solar cells: do polaronic energy levels play a role? Appl Phys Lett, 91, 243502 (2007). http://dx.doi.org/10.1063/1.2817930.

[17] Kymakis E, Servati P, Tzanetakis P, Koudoumas E, Kornilios N, Rompogiannakis I, Franghiadakis Y, Amaratunga GAJ. Effective mobility and photocurrent in carbon nanotube-polymer composite photovoltaic cells. Nanotechnology, 18, 435702 (2007). http:// dx.doi.org/10.1088/0957-4484/18/43/435702.

[18] Mihailetchi VD, Wildeman J, Blom PWM. Space-charge limited photocurrent. Phys Rev Lett, 94, 126602 (2005). http://dx.doi. org/10.1103/PhysRevLett.94.126602.

[19] Geens W, Shaheen SE, Wessling B, Brabec CJ, Poortmans J, Sariciftci NS. Dependence of field-effect hole mobility of PPV-based polymer films on the spin-casting solvent. Org Electron, 3, 105 (2002). http://dx.doi.org/10.1016/s1566-1199(02)00039-3.

[20] Bao Z, Dodabalapur A, Lovinger AJ. Soluble and processable regioregular poly(3-hexylthiophene) for thin film field-effect transistor applications with high mobility. Appl Phys Lett, 69, 4108 (1996). http://dx.doi.org/10.1063/1.117834.

[21] Sirringhaus H, Tessler N, Friend RH. Integrated optoelectronic devices based on conjugated polymers. Science, 280, 1741 (1998). http://dx.doi.org/10.1126/science.280.5370.1741.

[22] Yang CM, Liao HH, Horng SF, Meng HF, Tseng SR, Hsu CS. Electron mobility and electroluminescence efficiency of blue conjugated polymers. Synth Met, 158, 25 (2008). http://dx.doi. org/10.1016/j.synthmet.2007.11.006.

[23] Chirvase D, Chiguvare Z, Knipper M, Parisi J, Dyakonov V, Hummelen JC. Temperature dependent characteristics of poly(3 hexylthiophene)-fullerene based heterojunction organic solar cells. J App1 Phys, 93, 3376 (2003). http://dx.doi.org/10.1063/1.1545162.

[24] Kooistra FB, Knol J, Kastenberg F, Popescu LM, Verhees WJH, Kroon JM, Hummelen JC. Increasing the open circuit voltage of bulk-heterojunction solar cells by raising the LUMO level of the acceptor. Org Lett, 9, 551 (2007). http://dx.doi.org/10.1021/ ol062666p.

[25] Kooistra FB, Mihailetchi VD, Popescu LM, Kronholm D, Blom PWM, Hummelen JC. New C84 derivative and its application in a bulk heterojunction solar cell. Chem Mater, 18, 3068 (2006). http:// dx.doi.org/10.1021/cm052783z.

[26] Frankevich E, Maruyama Y, Ogata H. Mobility of charge carriers in vapor-phase grown C60 single crystal. Chem Phys Lett, 214, 39 (1993). http://dx.doi.org/10.1016/0009-2614(93)85452-T.

[27] Haddon RC, Perel AS, Morris RC, Palstra TTM, Hebard AF, Fleming RM. C60 thin film transistors. Appl Phys Lett, 67, 121 (1995). http://dx.doi.org/10.1063/1.115503.

[28] Wobkenberg PH, Bradley DDC, Kronholm D, Hummelen JC, de Leeuw DM, Colle M, Anthopoulos TD. High mobility n-channel organic field-effect transistors based on soluble C60 and C70 fullerene derivatives. Synth Met, 158, 468 (2008). http://dx.doi. org/10.1016/j.synthmet.2008.03.016.

[29] Singh TB, Marjanovic N, Stadler P, Auinger M, Matt GJ, Gunes S, Sariciftci NS, Schwodiauer R, Bauer S. Fabrication and characterization of solution-processed methanofullerene- based organic field-effect transistors. J Appl Phys, 97, 083714 (2005). http:// dx.doi.org/10.1063/1.1895466.

[30] Mihailetchi VD, Van Duren JKJ, Blom PWM, Hummelen JC, Janssen RAJ, Kroon JM, Rispens MT, Verhees WJH, Wienk MM. Electron transport in a methanofullerene. Adv Funct Mater, 13, 43 (2003). http://dx.doi.org/10.1002/adfm.200390004.

[31] Wienk MM, Kroon JM, Verhees WJH, Knol J, Hummelen JC, Van Hal PA, Janssen RAJ. Efficient methano[70]fullerene/MDMOPPV bulk heterojunction photovoltaic cells. Angew Chem Int Ed, 42, 3371 (2003). http://dx.doi.org/10.1002/anie.200351647.

[32] Li C, Chen Y, Wang Y, Iqbal Z, Chhowalla M, Mitra S. A fullerenesingle wall carbon nanotube complex for polymer bulk heterojunction photovoltaic cells. J Mater Chem, 17, 2406 (2007). http:// dx.doi.org/10.1039/b618518e.

[33] Tenent RC, Barnes TM, Bergeson JD, Ferguson AJ, To B, Gedvilas LM, Heben MJ, Blackburn JL. UItrasmooth, large-area, highuniformity, conductive transparent single-walled-carbon-nanotube films for photovoltaics produced by ultrasonic spraying. Adv Mater, 21, 3210 (2009). http://dx.doi.org/10.1002/adma.200803551.

[34] Zou J, Chen H, Chunder A, Yu Y, Huo Q, Zhai L. Preparation of a superhydrophobic and conductive nanocomposite coating from a carbon-nanotube-conjugated block copolymer dispersion. Adv Mater, 20, 3337 (2008). http://dx.doi.org/10.1002/adma.200703094.

[35] Rispens MT, Meetsma A, Rittberger R, Brabec CJ, Sariciftci NS, Hummelen JC. Influence of the solvent on the crystal structure of PCBM and the efficiency of MDMO-PPV:PCBM 'plastic' solar cells. Chem Commun, 9, 2116 (2003). http://dx.doi.org/10.1039/ B305988J.

[36] Shaheen SE, Brabec CJ, Sariciftci NS, Padinger F, Fromherz T, Hummelen JC. 2.5\% efficient organic plastic solar cells. Appl Phys Lett, 78, 841 (2001). http://dx.doi.org/10.1063/1.1345834.

[37] Brabec CJ, Cravino A, Meissner D, Serdar Sariciftci N, Fromherz T, Rispens MT, Sanchez L, Hummelen JC. Origin of the open circuit voltage of plastic solar cells. Adv Funct Mater, 11, 374 (2001). http://dx.doi.org/10.1002/1616-3028(200110)11:5<374::aid$\operatorname{adfm} 374>3.0 . c 0 ; 2-w$.

[38] Ma W, Yang C, Gong X, Lee K, Heeger AJ. Thermally stable, efficient polymer solar cells with nanoscale control of the interpenetrating network morphology. Adv Funct Mater, 15, 1617 (2005). http://dx.doi.org/10.1002/adfm.200500211.

[39] Dante M, Peet J, Nguyen TQ. Nanoscale charge transport and internal structure of bulk heterojunction conjugated polymer/fullerene solar cells by scanning probe microscopy. J Phys Chem C, 112, 7241 (2008). http://dx.doi.org/10.1021/jp712086q.

[40] Kim K, Liu J, Namboothiry MAG, Carroll DL. Roles of donor and acceptor nanodomains in 6\% efficient thermally annealed polymer photovoltaics. Appl Phys Lett, 90, 163511 (2007). http://dx.doi. org/10.1063/1.2730756.

[41] Mihailetchi VD, Koster LJA, Blom PWM, Melzer C, De Boer B, Van Duren JKJ, Janssen RAJ. Compositional dependence of the performance of poly(p-phenylene vinylene):Methanofullerene bulk-heterojunction solar cells. Adv Funct Mater, 15, 795 (2005). http://dx.doi.org/10.1002/adfm.200400345.

[42] Savenije TJ, Kroeze JE, Wienk MM, Kroon JM, Warman JM. Mobility and decay kinetics of charge carriers in photoexcited PCBM/PPV blends. Phys Rev B, 69, 155205 (2004). http://dx.doi. org/10.1103/PhysRevB.69.155205.

[43] Li G, Shrotriya V, Huang J, Yao Y, Moriarty T, Emery K, Yang Y. High-efficiency solution processable polymer photovoltaic cells by 
self-organization of polymer blends. Nature Mater, 4, 864 (2005). http://dx.doi.org/10.1038/nmat1500.

[44] Mihailetchi VD, Xie H, De Boer B, Koster LJA, Blom PWM. Charge transport and photocurrent generation in poly(3-hexylthiophene): methanofullerene bulk-heterojunction solar cells. Adv Funct Mater, 16, 699 (2006). http://dx.doi.org/10.1002/ adfm. 200500420.

[45] Moule AJ, Meerholz K. Morphology control in solution-processed bulk-heterojunction solar cell mixtures. Adv Funct Mater, 19, 3028 (2009). http://dx.doi.org/10.1002/adfm.200900775.

[46] Wei Q, Nishizawa T, Tajima K, Hashimoto K. Self-organized buffer layers in organic solar cells. Adv Mater, 20, 2211 (2008). http:// dx.doi.org/10.1002/adma.200792876.

[47] Cravino A, Sariciftci NS. Organic electronics: molecules as bipolar conductors. Nat Mater, 2, 360 (2003). http://dx.doi.org/10.1038/ nmat915.

[48] Cravino A, Sariciftci NS. Double-cable polymers for fullerene based organic optoelectronic applications. J Mater Chem, 12, 1931 (2002). http://dx.doi.org/10.1039/b201558g.

[49] Zhao GJ, He YJ, Li Y. 6.5\% efficiency of polymer solar cells based on poly(3-hexylthiophene) and indene-C60 bisadduct by device optimization. Adv Mater, 22, 4355 (2010). http://dx.doi. org/10.1002/adma.201001339.

[50] Konya Z, Vesselenyi I, Niesz K, Kukovecz A, Demortier A, Fonseca A, Delhalle J, Mekhalif Z, Nagy JB, Koos AA, Osvath Z, Kocsonya A, Biro LP, Kiricsi I. Large scale production of short functionalized carbon nanotubes. Chem Phys Lett, 360, 429 (2002). http://dx.doi.org/10.1016/s0009-2614(02)00900-4.

[51] Pierard N, Fonseca A, Konya Z, Willems I, Van Tendeloo G, Nagy JB. Production of short carbon nanotubes with open tips by ball milling. Chem Phys Lett, 335, 1 (2001). http://dx.doi.org/10.1016/ s0009-2614(01)00004-5.

[52] Khabashesku VN, Billups WE, Margrave JL. Fluorination of single-wall carbon nanotubes and subsequent derivatization reactions. Acc Chem Res, 35, 1087 (2002). http://dx.doi.org/10.1021/ ar020146y.

[53] Lim JK, Yun WS, Yoon MH, Lee SK, Kim CH, Kim K, Kim SK. Selective thiolation of single-walled carbon nanotubes. Synth Met, 139, 521 (2003). http://dx.doi.org/10.1016/s0379-6779(03)00337-0.

[54] Ma PC, Mo SY, Tang BZ, Kim JK. Dispersion, interfacial interaction and re-agglomeration of functionalized carbon nanotubes in epoxy composites. Carbon, 48, 1824 (2010). http://dx.doi. org/10.1016/j.carbon.2010.01.028.

[55] Yan D, Wang F, Zhao Y, Liu J, Wang J, Zhang L, Park KC, Endo M. Production of a high dispersion of silver nanoparticles on surface-functionalized multi-walled carbon nanotubes using an electrostatic technique. Mater Lett, 63, 171 (2009). http://dx.doi. org/10.1016/j.matlet.2008.09.018.

[56] Yang SJ, Choi JY, Chae HK, Cho JH, Nahm KS, Park CR. Preparation and enhanced hydrostability and hydrogen storage capacity of CNT@MOF-5 hybrid composite. Chem Mater, 21, 1893 (2009). http://dx.doi.org/10.1021/cm803502y.

[57] Hueso JL, Espinos JP, Caballero A, Cotrino J, Gonzalez-Elipe AR. XPS investigation of the reaction of carbon with $\mathrm{NO}, \mathrm{O} 2, \mathrm{~N} 2$ and H2O plasmas. Carbon, 45, 89 (2007). http://dx.doi.org/10.1016/j. carbon.2006.07.021.

[58] Tusek L, Nitschke M, Werner C, Stana-Kleinschek K, Ribitsch V. Surface characterisation of NH3 plasma treated polyamide 6 foils. Colloids Surf Physicochem Eng Aspects, 195, 81 (2001). http:// dx.doi.org/10.1016/s0927-7757(01)00831-7.

[59] Kim SW, Kim T, Kim YS, Choi HS, Lim HJ, Yang SJ, Park CR. Surface modifications for the effective dispersion of carbon nanotubes in solvents and polymers. Carbon, 50, 3 (2012). http://dx.doi. org/10.1016/j.carbon.2011.08.011.

[60] O'Connell MJ, Bachilo SH, Huffman CB, Moore VC, Strano MS, Haroz EH, Rialon KL, Boul PJ, Noon WH, Kittrell C, Ma J, Hauge RH, Weisman RB, Smalley RE. Band gap fluorescence from individual single-walled carbon nanotubes. Science, 297, 593 (2002). http://dx.doi.org/10.1126/science.1072631.

[61] Moore VC, Strano MS, Haroz EH, Hauge RH, Smalley RE, Schmidt J, Talmon Y. Individually suspended single-walled carbon nanotubes in various surfactants. Nano Lett, 3, 1379 (2003). http:// dx.doi.org/10.1021/n1034524j.

[62] Saini V, Li Z, Bourdo S, Dervishi E, Xu Y, Ma X, Kunets VP, Salamo GJ, Viswanathan T, Biris AR, Saini D, Biris AS. Electrical, optical, and morphological properties of $\mathrm{p} 3 \mathrm{ht}-\mathrm{mwnt}$ nanocomposites prepared by In situ polymerization. J Phys Chem C, 113, 8023 (2009). http://dx.doi.org/10.1021/jp809479a.

[63] Sui XM, Giordani S, Prato M, Wagner HD. Effect of carbon nanotube surface modification on dispersion and structural properties of electrospun fibers. Appl Phys Lett, 95, 233113 (2009). http:// dx.doi.org/10.1063/1.3272012.

[64] Kubota K, Sano M, Masuko T. Microwave irradiation for chemical modification of carbon nanotubes for better dispersion. Jpn J Appl Phys, 44, 465 (2005). http://dx.doi.org/10.1143/jjap.44.465.

[65] Yang K, Gu M. The effects of triethylenetetramine grafting of multi-walled carbon nanotubes on its dispersion, filler-matrix interfacial interaction and the thermal properties of epoxy nanocomposites. Polym Eng Sci, 49, 2158 (2009). http://dx.doi.org/10.1002/ pen.21461.

[66] Zhao W, Liu YT, Feng QP, Xie XM, Wang XH, Ye XY. Dispersion and noncovalent modification of multiwalled carbon nanotubes by various polystyrene-based polymers. J Appl Polym Sci, 109, 3525 (2008). http://dx.doi.org/10.1002/app.28453.

[67] Yan Y, Cui J, Potschke P, Voit B. Dispersion of pristine singlewalled carbon nanotubes using pyrene-capped polystyrene and its application for preparation of polystyrene matrix composites. Carbon, 48, 2603 (2010). http://dx.doi.org/10.1016/j.carbon. 2010.03.065.

[68] Zou J, Liu L, Chen H, Khondaker SI, McCullough RD, Huo Q, Zhai L. Dispersion of pristine carbon nanotubes using conjugated block copolymers. Adv Mater, 20, 2055 (2008). http://dx.doi. org/10.1002/adma.200701995.

[69] Zhang Z, Che Y, Smaldone RA, Xu M, Bunes BR, Moore JS, Zang L. Reversible dispersion and release of carbon nanotubes using foldable oligomers. J Am Chem Soc, 132, 14113 (2010). http:// dx.doi.org/10.1021/ja104105n.

[70] Lovell CS, Wise KE, Kim JW, Lillehei PT, Harrison JS, Park C. Thermodynamic approach to enhanced dispersion and physical properties in a carbon nanotube/polypeptide nanocomposite. Polymer, 50, 1925 (2009). http://dx.doi.org/10.1016/j.polymer.2009.02.016.

[71] Sun G, Chen G, Liu J, Yang J, Xie J, Liu Z, Li R, Li X. A facile gemini surfactant-improved dispersion of carbon nanotubes in polystyrene. Polymer, 50, 5787 (2009). http://dx.doi.org/10.1016/j. polymer.2009.10.007.

[72] Hermant MC, Klumperman B, Kyrylyuk AV, Van Der Schoot P, Koning CE. Lowering the percolation threshold of single-walled 
carbon nanotubes using polystyrene/poly(3,4-ethylenedioxythiophene): poly(styrene sulfonate) blends. Soft Matter, 5, 878 (2009). http://dx.doi.org/10.1039/b814976c.

[73] Arnold MS, Stupp SI, Hersam MC. Enrichment of single-walled carbon nanotubes by diameter in density gradients. Nano Lett, $\mathbf{5}$, 713 (2005). http://dx.doi.org/10.1021/n1050133o.

[74] Yu B, Hou PX, Li F, Liu B, Liu C, Cheng HM. Selective removal of metallic single-walled carbon nanotubes by combined in situ and post-synthesis oxidation. Carbon, 48, 2941 (2010). http://dx.doi. org/10.1016/j.carbon.2010.04.032.

[75] Cordeiro CE, Delfino A, Frederico T. Theoretical study of work function of conducting single-walled carbon nanotubes by a nonrelativistic field theory approach. Carbon, 47, 690 (2009). http:// dx.doi.org/10.1016/j.carbon.2008.11.004.

[76] Ago $\mathrm{H}$. Work functions and surface functional groups of multiwall carbon nanotubes. J Phys Chem B, 103, 8116 (1999). http://dx.doi. org/10.1021/jp991659y.

[77] Lee JM, Park JS, Lee SH, Kim H, Yoo S, Kim SO. Selective electron- or hole-transport enhancement in bulk-heterojunction organic solar cells with N- or B-doped carbon nanotubes. Adv Mater, 23, 629 (2011). http://dx.doi.org/10.1002/adma.201003296.

[78] Kymakis E, Amaratunga GAJ. Single-wall carbon nanotube/conjugated polymer photovoltaic devices. Appl Phys Lett, 80, 112 (2002). http://dx.doi.org/10.1063/1.1428416.

[79] Landi BJ, Raffaelle RP, Castro SL, Bailey SG. Single-wall carbon nanotube-polymer solar cells. Prog Photovolt Res Appl, 13, 165 (2005). http://dx.doi.org/10.1002/pip.604.

[80] Nogueira AF, Lomba BS, Soto-Oviedo MA, Correia CRD, Corio P, Furtado CA, Hümmelgen IA. Polymer solar cells using single-wall carbon nanotubes modified with thiophene pedant groups. J Phys Chem C, 111, 18431 (2007). http://dx.doi.org/10.1021/jp074979n.

[81] Bhattacharyya S, Kymakis E, Amaratunga GAJ. Photovoltaic properties of dye functionalized single-wall carbon nanotube/ conjugated polymer devices. Chem Mater, 16, 4819 (2004). http:// dx.doi.org/10.1021/cm0496063.

[82] Berson S, De Bettignies R, Bailly S, Guillerez S, Jousselme B. Elaboration of $\mathrm{P} 3 \mathrm{HT} / \mathrm{CNT} / \mathrm{PCBM}$ composites for organic photovoltaic cells. Adv Funct Mater, 17, 3363 (2007). http://dx.doi. org/10.1002/adfm.200700438.

[83] Hatton RA, Blanchard NP, Tan LW, Latini G, Cacialli F, Silva SRP. Oxidised carbon nanotubes as solution processable, high work function hole-extraction layers for organic solar cells. Org Electron, 10, 388 (2009). http://dx.doi.org/10.1016/j.orgel.2008.12.013.

[84] Pradhan B, Batabyal SK, Pal AJ. Functionalized carbon nanotubes in donor/acceptor-type photovoltaic devices. Appl Phys Lett, 88, 093106 (2006). http://dx.doi.org/10.1063/1.2179372.

[85] Yang SJ, Park CR. Facile preparation of monodisperse ZnO quantum dots with high quality photoluminescence characteristics. Nanotechnology, 19, 035609 (2008). http://dx.doi.org/10.1088/09574484/19/03/035609.

[86] Ago H, Petritsch K, Shaffer MSP, Windle AH, Friend RH. Composites of carbon nanotubes and conjugated polymers for photovoltaic devices. Adv Mater, 11, 1281 (1999). http://dx.doi.org/10.1002/ (sici)1521-4095(199910)11:15<1281::aid-adma1281>3.0.co;2-6.

[87] Hecht DS, Hu L, Irvin G. Emerging transparent electrodes based on thin films of carbon nanotubes, graphene, and metallic nanostructures. Adv Mater, 23, 1482 (2011). http://dx.doi.org/10.1002/ adma.201003188.

[88] Yun D, Feng W, Wu H, Li B, Liu X, Yi W, Qiang J, Gao S, Yan
S. Controllable functionalization of single-wall carbon nanotubes by in situ polymerization method for organic photovoltaic devices. Synth Met, 158, 977 (2008). http://dx.doi.org/10.1016/j.synthmet.2008.06.025.

[89] Landi BJ, Castro SL, Ruf HJ, Evans CM, Bailey SG, Raffaelle RP. CdSe quantum dot-single wall carbon nanotube complexes for polymeric solar cells. Sol Energy Mater Sol Cells, 87, 733 (2005). http://dx.doi.org/10.1016/j.solmat.2004.07.047.

[90] Kymakis E, Kornilios N, Koudoumas E. Carbon nanotube doping of P3HT : PPPCBM photovoltaic devices. J Phys D: Appl Phys, 41, 165110 (2008). http://dx.doi.org/10.1088/0022-3727/41/16/165110.

[91] Stylianakis MM, Mikroyannidis JA, Kymakis E. A facile, covalent modification of single-wall carbon nanotubes by thiophene for use in organic photovoltaic cells. Sol Energy Mater Sol Cells, 94, 267 (2010). http://dx.doi.org/10.1016/j.solmat.2009.09.013.

[92] Novoselov KS, Geim AK, Morozov SV, Jiang D, Zhang Y, Dubonos SV, Grigorieva IV, Firsov AA. Electric field in atomically thin carbon films. Science, 306, 666 (2004). http://dx.doi.org/10.1126/ science. 1102896.

[93] Park S, Ruoff RS. Chemical methods for the production of graphenes. Nature Nanotechnol, 4, 217 (2009). http://dx.doi. org/10.1038/nnano.2009.58.

[94] Nagashio K, Nishimura T, Kita K, Toriumi A. Mobility variations in mono- and multi-layer graphene films. Appl Phys Express, 2, 025003 (2009). http://dx.doi.org/10.1143/apex.2.025003.

[95] McCann E. Asymmetry gap in the electronic band structure of bilayer graphene. Phys Rev B, 74, 161403 (2006). http://dx.doi. org/10.1103/PhysRevB.74.161403.

[96] Han MY, Ozyilmaz B, Zhang Y, Kim P. Energy band-gap engineering of graphene nanoribbons. Phys Rev Lett, 98, 206805 (2007). http://dx.doi.org/10.1103/PhysRevLett.98.206805.

[97] Boukhvalov DW, Katsnelson MI. Tuning the gap in bilayer graphene using chemical functionalization: density functional calculations. Phys Rev B, 78, 085413 (2008). http://dx.doi.org/10.1103/ PhysRevB.78.085413.

[98] Avouris P. Graphene: electronic and photonic properties and devices. Nano Lett, 10, 4285 (2010). http://dx.doi.org/10.1021/ nl102824h

[99] Du X, Skachko I, Barker A, Andrei EY. Approaching ballistic transport in suspended graphene. Nature Nanotechnol, 3, 491 (2008). http://dx.doi.org/10.1038/nnano.2008.199.

[100] Yu YJ, Zhao Y, Ryu S, Brus LE, Kim KS, Kim P. Tuning the graphene work function by electric field effect. Nano Lett, 9, 3430 (2009). http://dx.doi.org/10.1021/n1901572a.

[101] Li X, Wang X, Zhang L, Lee S, Dai H. Chemically derived, ultrasmooth graphene nanoribbon semiconductors. Science, 319, 1229 (2008). http://dx.doi.org/10.1126/science.1150878.

[102] Stankovich S, Dikin DA, Piner RD, Kohlhaas KA, Kleinhammes A, Jia Y, Wu Y, Nguyen ST, Ruoff RS. Synthesis of graphenebased nanosheets via chemical reduction of exfoliated graphite oxide. Carbon, 45, 1558 (2007). http://dx.doi.org/10.1016/j.carbon.2007.02.034.

[103] Muszynski R, Seger B, Kamat PV. Decorating graphene sheets with gold nanoparticles. J Phys Chem C, 112, 5263 (2008). http:// dx.doi.org/10.1021/jp800977b.

[104] Pei S, Zhao J, Du J, Ren W, Cheng HM. Direct reduction of graphene oxide films into highly conductive and flexible graphene films by hydrohalic acids. Carbon, 48, 4466 (2010). http://dx.doi. org/10.1016/j.carbon.2010.08.006. 
[105] Gao W, Alemany LB, Ci L, Ajayan PM. New insights into the structure and reduction of graphite oxide. Nature Chem, 1, 403 (2009). http://dx.doi.org/10.1038/nchem.281.

[106] Compton OC, Jain B, Dikin DA, Abouimrane A, Amine K, Nguyen ST. Chemically active reduced graphene oxide with tunable C/O ratios. ACS Nano, 5, 4380 (2011). http://dx.doi.org/10.1021/ nn1030725.

[107] Li SS, Tu KH, Lin CC, Chen CW, Chhowalla M. Solution-processable graphene oxide as an efficient hole transport layer in polymer solar cells. ACS Nano, 4, 3169 (2010). http://dx.doi. org/10.1021/nn100551j.

[108] Liu Q, Liu Z, Zhang X, Zhang N, Yang L, Yin S, Chen Y. Organic photovoltaic cells based on an acceptor of soluble graphene. Appl Phys Lett, 92, 223303 (2008). http://dx.doi.org/ 10.1063/1.2938865.

[109] Hill CM, Zhu Y, Pan S. Fluorescence and electroluminescence quenching evidence of interfacial charge transfer in poly (3-hexylthiophene): graphene oxide bulk heterojunction photovoltaic devices. ACS Nano, 5, 942 (2011). http://dx.doi.org/10.1021/ nn1022457.

[110] Liu Z, Liu Q, Huang Y, Ma Y, Yin S, Zhang X, Sun W, Chen Y. Organic photovoltaic devices based on a novel acceptor material: graphene. Adv Mater, 20, 3924 (2008). http://dx.doi.org/10.1002/ adma.200800366.

[111] Yu D, Park K, Durstock M, Dai L. Fullerene-grafted graphene for efficient bulk heterojunction polymer photovoltaic devices. J Phys Chem Lett, 2, 1113 (2011). http://dx.doi.org/10.1021/jz200428y.

[112] Ryu MS, Jang J. Effect of solution processed graphene oxide/ nickel oxide bi-layer on cell performance of bulk-heterojunction organic photovoltaic. Sol Energy Mater Sol Cells, 95, 2893 (2011). http://dx.doi.org/10.1016/j.solmat.2011.06.008.

[113] Yin B, Liu Q, Yang L, Wu X, Liu Z, Hua Y, Yin S, Chen Y. Buffer layer of PEDOT:PSS/graphene composite for polymer solar cells. J Nanosci Nanotechnol, 10, 1934 (2010). http://dx.doi. org/10.1166/jnn.2010.2107.

[114] Tu KH, Li SS, Li WC, Wang DY, Yang JR, Chen CW. Solution processable nanocarbon platform for polymer solar cells. Energy Environ Sci, 4, 3521 (2011). http://dx.doi.org/10.1039/ c1ee01333e.

[115] Liu Q, Ren W, Chen ZG, Yin L, Li F, Cong H, Cheng HM. Semiconducting properties of cup-stacked carbon nanotubes. Carbon, 47, 731 (2009). http://dx.doi.org/10.1016/j.carbon.2008.11.005.

[116] Zhu H, Wei J, Wang K, Wu D. Applications of carbon materials in photovoltaic solar cells. Sol Energy Mater Sol Cells, 93, 1461 (2009). http://dx.doi.org/10.1016/j.solmat.2009.04.006. 